\title{
Generosity as Freedom in Spinoza's Ethics
}

\author{
Hasana Sharp
}

In this chapter, through attention to the virtue of generosity, I offer an alternative solution to the puzzle Daniel Garber presents in his 1994 paper on sociability and freedom in Spinoza's Ethics. Garber identifies a tension within Spinoza's doctrine, according to which (i) freedom is the ability to be an adequate cause of one's own actions and (ii) freedom entails the desire for friendship, society, and mutual aid. ${ }^{1}$ Freedom as adequate causation seems to imply self-sufficiency, but Spinoza frequently links the desire for sociability to our unavoidable lack of self-sufficiency. In the Political Treatise, Spinoza observes that "it's futile for one person alone to try to protect himself from all others," ${ }^{32}$ and for this reason each of us intrinsically fears solitude. ${ }^{3}$ In the Ethics, immediately after invoking the adage "Man is a God to Man," Spinoza's thoughts turn to the prosaic: "Men still find by experience that by helping each other they can provide themselves much more easily with the things they require, and that only by joining forces can they avoid the dangers which threaten on all sides." ${ }^{\prime}$ Society thus appears to be a response to our vulnerability and finitude. Spinoza often frames the desire for society in negative terms, as a mode of protection from violence, the elements, and deprivation, which protection is necessary given the limited powers of individuals. ${ }^{5}$

But Spinoza also positively aligns freedom, rationality, and sociability throughout his writings. Spinoza asserts that one who exercises virtueunderstood as the power and freedom proper to one's nature-necessarily strives for society and the well-being of others. "The good which everyone who seeks virtue wants for himself, he also desires for other men."' The guidance of reason directs each to persevere in her own being and, concomitantly, to pursue the shared enjoyment of common goods. ${ }^{7}$ Despite Spinoza's multiple assertions that rationality entails sociability, Garber finds that he "has no real 
arguments to that conclusion." Garber thus proposes the following: sociability, cooperation, and interdependence follow from one's desire for freedom, but not from its attainment. While sociability is a necessary means to freedom, it is not a consequence of it. Since sociability involves dependency on others rather than self-sufficiency, on his account, it must express our neediness rather than our power.

Attention to generosity as an expression of freedom, I suggest, points toward a different way to dissolve the dilemma. It is certainly true that Spinoza often argues from our finitude to the necessity and indissolubility of social order in general. Nevertheless, need is not the only basis of sociability. Insofar as we are rational, free, and virtuous, we exercise hard-won social skills, such as generosity. Generosity, defined as the rational desire to aid other men and join them in friendship, is a powerful art of joining together with others that is no less difficult and rare than other practices of natural science. Generosity, I hope to show, is not best understood as an alliance of forces, necessary for mortal beings with limited time and skills. Sociability as generosity exceeds the realm of need and follows directly from our strength of character [fortitudo], because it expresses a positive power to overcome anti-social passions, such as hatred, envy, and the desire for revenge. Spinoza asserts that generous souls resist and overwhelm hostile forces and debilitating affects with wisdom, foresight, and love. ${ }^{9}$ The sociability yielded by generosity, then, is not just a form of cooperation we need to survive and produce leisure for study and contemplation. Generosity is not a mere means but a positive expression of freedom, because it is the activity through which a strong soul (and body) transforms enemies into friends. It is not an expression of lack, but of an acquired power that infuses one's social milieu with empowering love and joy, creating agreements in nature and power where they did not previously exist. Attention to generosity reveals not only that there are social virtues proper to Spinoza's understanding of freedom but that freedom itself is, by necessity, social.

Difficulties of interpretation arise partly because Spinoza's account of finite life as immanent and ineluctably relational implies that freedom is not a binary phenomenon, something we have or do not have, but something that complicates oppositions between activity and passivity, affecting and being affected. Attention to generosity helps address the complexity of freedom as both a product of necessity and as a matter of degree. Although I can only provide a small window into the full set of questions raised by consideration of the relationship between sociability and freedom, I will try to address two. The first is metaphysical, and is the primary source of concern for Garber. How can one be understood both 
to act "from one's nature alone" and to act with others? How can we reconcile adequate causation with acting through community [convenientia]? The second may be more phenomenological. The constellation of social virtues expressive of fortitudo that Spinoza names evoke self-limitation: generosity, modesty, clemency, and chastity. How do these traditionally Christian virtues cohere with Spinoza's activist, or Machiavellian, conception of virtue? I will address these two issues in turn.

\section{Acting by Oneself with Others}

Spinoza defines virtue as "power," or "the very essence, or nature, of man, insofar as he has the power of bringing about certain things which can be understood through the laws of his nature alone."10 Since only substance acts absolutely without the concurrence of other causes, only God or Nature can be understood as entirely self-sufficient, as the exclusive cause of its effects. The complex individuals we call "humans" do not cause anything absolutely, but they do serve as "adequate causes" of some of their actions. ${ }^{11}$ Spinoza stipulates that "I call that cause adequate whose effect can clearly and distinctly be perceived through it. But I call it partial, or inadequate, if its effect cannot be understood through it alone." ${ }^{12}$ Garber interprets human action to be adequate only if it is, in some sense, "causally isolated from the rest of the world," such that one would affect others without being at the same time affected by them. Since finite beings are never entirely unaffected by others, they can only ever be partially free and rational. He suggests, therefore, that Spinoza's figure of virtue-a man whose acts can be understood through the laws of his nature alone-must be an idealization. ${ }^{13}$ When Spinoza attaches reason, freedom, and virtue to sociability-as he does with the notion of generosity-Garber suggests that we understand sociability as belonging to the desire for freedom rather than to its achievement. ${ }^{14}$

There can be no question that sociability serves as a condition of possibility for freedom, virtue, and reason. We are born radically dependent, ignorant, and highly susceptible to the aleas of fortune. We would not live without the ministrations of our caretakers who themselves could not provide nourishment or induce in us enabling passions without a more or less elaborate network of social relations. We require education, political order, and a division of labor to become the kinds of beings who are increasingly "conscious of [ourselves], God, and things." ${ }^{15}$ Certainly, there would be no freedom, no power to produce effects 
that follow from our natures, without sociality. Sociability is a necessary, albeit not sufficient, condition of freedom. We cannot become free all by ourselves. Infants raised by wolves, who are harshly abused or severely deprived, do not develop those powers that enable them to do what follows from "the laws" of a nature Spinoza would describe as human. Nevertheless, Spinoza is not being imprecise when he asserts that sociability is also a result of virtue. Indeed, generosity is an example of how acting "solely under the guidance of reason" entails sociability directly.

Generosity appears at the end of Part 3 of Spinoza's Ethics, in his discussion of active affects. While human life is invariably characterized by subjection to the passions and to the common order of Nature, ${ }^{16}$ we necessarily strive, with more or less success, to do those things that follow from and enhance our particular natures. ${ }^{17}$ But what does it mean to do what "follows from one's nature?" Must one be absolute-unconnected and untied to anything else-in order to act, according to Spinoza? I do not think so. In fact, we could not act if we were alone or absolved of relations with others. Human activity is not the pure self-activity of God or Nature as a whole. We produce active affects (or act) insofar as we have bodies and (thus also) minds ordered in such a way that they can produce effects from their own resources. In other words, as I understand Spinoza, active affects express virtue because they are activities that follow from a relationship of forces within a composite individual as well as those powers that "agree with" that individual's nature. An active affect, he tells us, is always related to joy or desire ${ }^{18}$ which means that it indicates an amplification of our power. Rather than explaining an increase in one's power to think and act by a fortunate encounter with external forces - such as the uplift in mood delivered by the warm sunactive affects must be explained by a favorable change in one's ability to think and act that the virtuous agent produces from her "own" resources, but what counts as one's own includes "external" powers that preserve and enhance one's vitality and power. ${ }^{19}$ Spinoza describes very few active affects, but among them is generosity.

Generosity is defined as a desire to aid others and join them to oneself in friendship that is guided solely by reason. Since reason is its exclusive cause, generosity should be understood as an expression of virtue, or power, which follows from the laws of one's nature alone. ${ }^{20}$ Spinoza calls desire the "essence" of man, but a human's essence (or nature) is not typically guided by reason alone: "The essence of the mind is constituted by adequate and by inadequate ideas." ${ }^{21}$ We strive to think and act from confusion and imagination as well as from clarity and understanding. But when we desire from understanding, we 
express fortitudo, strength of character or mind, which, Spinoza tells us, is distinguished by particular active affects: animositas and generositas. Animositas names the desire spurred by reason to persevere and aims at the agent's good [utile]. ${ }^{22}$ Spinoza's dictates of reason clearly link virtue to the desire to persevere in being, and so there is nothing puzzling about courage, or the intelligent desire to persevere, being proper to strength of character. We might note, however, that Spinoza defines the agent's good, or utile, as whatever enables the body to affect others and to be affected, in increasingly many ways. ${ }^{23}$ The power of the agent, for Spinoza, unambiguously includes a power of receptivity as well as a power of assertion. The good, power, and virtue of an actor are his or her power to coordinate with others, to join forces, and to be transformed in enabling ways by other modes in nature. Spinoza's general rule that our minds grow in sophistication as our bodies become capable of being disposed in increasingly many ways further underlines how susceptibility to connection is a key feature of a finite mode's agency. ${ }^{24}$ If what we need in order to think and act more powerfully is an increasingly complex power of receptivity, then causal isolation, or even independence more generally, is not an apt regulative ideal for becoming free. And neither does causal isolation, or radical independence, provide a picture of what it is to be free. Finite modes are not substance(s). Our freedom is not and should not strive to be absolute, unhinged from society and social relations.

When we conceive of courageous striving as a desire to persevere through affecting and disposing oneself toward being affected in enabling ways, reason's compulsion toward generosity may seem less paradoxical. Spinoza asserts that the agent of virtue is moved by reason [ex solo rationis dictamine] to aid other men and join with them in friendship. He doesn't describe generosity primarily as a receptive power, so we ought not understand courage as the active side of reason's striving in contrast to generosity as the passive side. Both animositas and generositas are active affects, or what a strong-minded character does by virtue of that strength. Generosity follows from the mind insofar as it understands. It does not merely provide the conditions amenable to understanding. Rather, generosity is understanding's effect. While there can be no question that connectivity, such as that between a mother's body and her fetus, brings into being activity, Spinoza insists also that virtuous activity, as generosity, also produces connectivity, or the coming together of diverse agential forces.

For Descartes, as Chantal Jaquet points out, helping others is a "property" of generosity but not its essence. ${ }^{25}$ Cartesian generosity is esteem that follows from the true understanding that nothing truly belongs to me other than my 
free control of my volitions. It is a feeling of resolve to use my will well, and only to praise or blame myself or others only on the basis of how we dispose our wills. ${ }^{26}$ Freedom, as free will, is at the basis of Cartesian generosity, and sociability is encouraged by generosity, but is not proper to its definition. Thus, the connection between freedom, generosity, and sociability is not as tight as it is in Spinoza. Spinozan generosity is defined equally by freedom and sociability. Since Spinoza plainly rejects freedom as the free control of one's volitions, we are operating with a different understanding of both generosity and freedom.

Freedom for Spinoza is not a faculty proper to our kind, identical in each human being, aligning him or her with God, as it is for Descartes. ${ }^{27}$ Whereas for Descartes generosity serves as the basis for something like respect, or proper moral regard of oneself and others, for Spinoza generosity is a hard-won ability to align not with God but with other people in a mutually enabling way. Like Descartes, however, the concept of generosity points toward a commonality. The commonality for Descartes is given by our inviolable freedom of will. In Spinoza it is made possible by the shared laws of our nature, but nevertheless needs to be developed by those who exercise fortitude.

At the risk of excessive repetition, I note again that freedom, or virtue, is the power to act from the necessary laws of one's nature. This idea remains somewhat unclear, and interpreters certainly do not have the same understanding of what these laws must refer to. Generally, for finite modes, the power to exist and act is something that arises between us, by virtue of the necessary laws that govern our shared existence. Some of these laws are entirely general. For example, each body is composed of a particular ratio of motion and rest. And beings on earth are subject to gravity. A singular, finite mode "can neither exist nor act unless it has been determined to exist and produce an effect by another cause, which also has a determinate and finite existence. ${ }^{28}$ We only exist and act at all because we are involved with infinitely many other finite beings. And we are more or less active to the extent that we concur with those other finite beings. As the example of an infant reminds us, not just any kind of concurrence will do. There are particular practices, bodies, and things most able to amplify our physical and mental power at a given time. And if our powers combine in mutually enabling ways, he maintains that we "agree in nature." Thus, Spinoza observes:

If [someone] lives among such individuals as agree with his nature, his power of acting will thereby be aided and encouraged. On the other hand, if he is among men who do not at all agree with his nature, he will hardly be able to accommodate himself to them without greatly changing himself. ${ }^{29}$ [E4app7] 
The concurrence or hostility of ambient modes is to a great extent a matter of fortune, or that which exceeds our power. Since we cannot but imitate the affects of those around us, especially those whose bodies and minds share the most with our own, the extent to which we can preserve and increase our power is strongly affected by the virtue (or lack thereof) of those around us. ${ }^{30}$ Even if one necessarily finds oneself in a social milieu that amplifies one's powers more or less, the ability of those among us to move us with joy and wisdom is owed to their virtuous generosity.

Generosity, for Spinoza, is the capacity to transform others through the exercise of one's own joyful wisdom, an ability which follows necessarily from virtue. Spinoza observes that "because, among singular things, we know nothing more excellent than a man who is guided by reason, we can best show how much our skill and understanding are worth [quantum arte et ingenio valeat] by educating men so that at last they live according to the command of their own reason." As often happens, Spinoza's remarks immediately acknowledge the contrary as well: people can be awful, can oppose one another bitterly, and are more dangerous than other individuals in nature. Spinoza continues, "Minds, however, are conquered not by arms but by love and generosity."31 He proceeds to remark on the supreme utility of friendship, but warns that "skill and alertness," ars et vigilantia, are necessary for this. The value of reason, then, appears in the generous power of sociability, a practical art of producing and strengthening friendships by bringing others to the threshold of their own reason.

When one acts to enhance the concurrence of powers among neighbors, we ought to understand this to be something that follows from one's nature, even if it ought not be attributed to an individual's exclusive activity. Let us observe with Balibar that when Spinoza elaborates his definition of conatus as the "actual essence" of each thing, he says:

From the given essence of each thing some things necessarily follow, and things are able to produce nothing but what follows from their determinate nature. So the power of each thing, or the striving by which it (either alone or with others) does anything $[\ldots]$ is nothing but the actual essence of the thing. ${ }^{32}$ [E3p6d]

Spinoza defines the essence of an actual thing not only by what it accomplishes independently but also by what it brings about through a concurrence of activity with others. This suggests that "our nature" is not circumscribed by what we customarily think of as our anthropomorphic individuality. Moreover, what can be understood through "the laws of our nature alone" is not only what can be attributed to our exclusive authorship. I do not think that the laws of our nature indicate 
some kind of given human nature to will freely or to reason. But they do point to abilities to think and act that are characteristic of those "like us," and the more we can generate compatibilities, the more we can produce local regularities or laws that predictably produce fortitude. Generosity, I suggest, is that power to generate convenientia, such that the scope of what follows from our nature is enlarged. Freedom as necessary activity-rather than as given faculty-involves the alignment and coordination of diverse powers. Generosity is one such description of the skill by which commonality and convenientia are brought into being.

\section{Militant Generosity}

Today we associate generosity with benevolence, altruism, and supererogatory acts. Several of the affects that Spinoza associates with fortitudo similarly suggest renunciation and self-limitation more than vitality and power. The sub-species of courage and generosity-sobriety, moderation, modesty, and chastity-are not what we typically associate with self-actualization. ${ }^{33}$ Despite the Christian resonance of pointing to modesty and chastity as expressions of the soul's power, Spinoza's ethics do not paint a portrait of freedom as a spiritual fortress, a power to disengage from the trivialities of earthly life, or a determination to retreat into the self. On my interpretation, Spinoza does not advocate the maxim of Descartes's provisional morality, recommending that, in the absence of certainty about what to do, we work more on ourselves than on fortune. ${ }^{34}$ Or perhaps better, Spinoza recommends that we work on the forces of fortune such that they may become our own. I suggest that Spinoza's account of generosity and the affects that flow from it, modestia and clementia, imply Spinoza's activist posture toward fortune. We will see again that freedom as a social power calls further into question the boundaries between the powers we attribute to others and those we might rightfully call our own.

Spinoza defines modestia as "a desire to do what pleases men and not what displeases them" [cupiditas ea faciendi quae hominibus placent et omittendi quae displicent..$^{35}$ Modesty is a species of ambition, which is defined in the same way, but is not typically guided by reason. ${ }^{36}$ Ambition often prompts us to please others through impressing them, distinguishing ourselves, and endeavoring to display our superiority. Yet the desire to be a source of joy to others expresses strength when guided by reason, because it involves the "skill and temperament" that produce an enduring augmentation in their power to think and act. Rather than briefly producing joy through a spectacular act, as standard ambition might involve, 
modestia produces joy in others through offering a more enduring and complete pleasure, like, for example, the ability to identify plants, interpret a text, or regard oneself as an instance of perfection. Modestia, although not precisely what we tend to mean in English by "modesty," is distinguished from ambition because it does not involve displaying our heroic distinction. ${ }^{37}$ Instead, modestia follows from enjoying together those goods that are more enjoyable the more they are shared..$^{38}$

But because, as Spinoza frequently laments, social life often involves being harmed by others, remaining determined by active affects rather than sad passions also requires clementia. We need that strength of character that enables us "to bear men's wrongs calmly, and apply [our] zeal to those things which help to bring men together in friendship." ${ }^{39}$ If we remind ourselves frequently that "men, like other things, act from the necessity of nature, then the wrong, or the hate usually arising from it will occupy a very small part of the imagination and easily be overcome." ${ }^{40}$ Whereas Descartes contends that generosity disposes one to interpret another's acts as following from her free will, Spinoza declares that imagining one another to be determined by necessity is what promises to deliver us from hatred, envy, mockery, and other sad passions. ${ }^{41}$ Clementia is a power of mind because it is grounded in understanding men, including oneself, "as they are and not as we would like them to be." ${ }^{\text {22 }}$ Through appreciating the rich network of causes within which humans operate, we are freed from the misery of a life fueled by hatred and vengeance. ${ }^{43}$ Forgiveness, or clemency, then, expresses a strength of soul rather than a repudiation of an individual's desire. It involves strength of mind directly because our tranquility enables us to understand ourselves and others more adequately. And insofar as it enables us to focus on the means to engender friendship rather than the means to satisfy our longing for vengeance, it contributes to the genuine fund of our power to think and act: sociality.

Spinoza consistently contrasts the desire for retribution, revenge, and war with generosity ${ }^{44}$ Generosity is an alternative, non-belligerent mode by which we can overcome hostile forces. Nonetheless, when Spinoza declares that the other's hate should not be repaid in kind, but should be "conquered" by love and generosity, he uses martial language. Generosity involves actively disrupting and overpowering the violence of social antagonism. In Spinoza's words,

One who is eager to overcome hate by love, strives joyously and confidently, resists many men as easily as one, and requires the least help of fortune. Those whom he conquers will yield joyously, not from lack of strength, but from an increase in their powers. [E4p46s]

Generosity, most essentially, is that power to turn haters into lovers, transmuting hostile forces into one's own arms. More evocative of Machiavelli's Prince than of 
Jesus Christ, ${ }^{45}$ Spinozan generosity is not a spiritual largesse that humbly defers judgment to God. Rather, generosity actively works on and against the forces of hatred to produce new alignments of shared power, pleasure, and knowledge.

Generosity conveys strength rather than weakness, power rather than need, if we reflect on Spinoza's remarks that, in a hostile environment, it is very difficult to withstand the desire to react with hatred or cruelty. ${ }^{46}$ Joining others to oneself is not only a matter of having more hands to accomplish what yours alone cannot. It is primarily a matter of responding to adversity with love rather than weakness. To join others to ourselves, especially those others who provoke intense sad passions in us, requires a powerful soul and body, a mode of being that is not easily perturbed, upset, or disintegrated by trauma. Instead, the generous emit joy and desire so powerfully that, instead of imitating the hatred of others, those same others imitate the generous, yielding joyously. Because their hostility yields to admiration, those who might have been enemies become friends. ${ }^{47}$ Generosity forges relations of agreement [convenientia] where they did not previously exist. The strong of soul exercise generosity when, rather than being changed by adversity, they overwhelm it with their own joyful radiations. In overcoming the hostile affects of others, modest generosity upsets the push-pull of struggles for domination with a common striving for shared power and joy. It is only great virtue and power that can re-order not only one's perspective on fortune but fortune itself.

\section{Notes}

1 Daniel Garber, "Dr. Fischelson's dilemma: Spinoza on freedom and sociability, in Spinoza on Reason and the "Free Man," ed. Yirmiyahu Yovel and Gideon Segal (New York: Little Room Press, 1994).

2 TP, ch. ii, $\$ 15$.

3 TP, ch. vi, $\$ 1$.

4 E4p35s.

5 TTP, ch. v, $\$ 7$.

6 E4p37.

7 For example, E4p18, E4p35, E4p37.

8 Garber, "Dr. Fischelson's dilemma," 191.

$9 \quad$ E4p46 and E5p10s.

10 E4d8.

11 E2p47.

12 E4d1.

13 Garber, "Dr. Fischelson's dilemma," 204. I agree with Matthew Homan's interpretation (on this point) in "Rehumanizing Spinoza's Free Man," in Doing 
without Free Will: Spinoza and Contemporary Moral Problems, ed. Ursula

Goldenbaum and Christopher Kluz (Lexington, KY: Rowman and Littlefield, 2015).

14 Garber, “Dr. Fischelson's dilemma," 195.

15 E5p39s.

16 E4p4.

17 There is a lively debate about whether Spinoza means to say that a man strives to enhance his singular nature, or whether man strives to enhance "human nature" as such. Without being able to justify this here, I interpret Spinoza to maintain that each human mode has a singular striving, or essence, and that there is no common essence we could call "human" that is given by nature. Insofar as we have shared properties, they are common notions and therefore not essences (by E2p37).

18 E3p59.

19 E3da2.

20 E3p59s.

21 E3p9d.

22 E3p59s.

23 E4p38.

24 E2p14.

25 Chantal Jaquet, "La fortitude cachée et les affects actifs de fermeté et générosité," in Fortitude et Servitude : Lectures de l'Éthique IV de Spinoza, ed. Chantal Jaquet, Pacal Sévérac, and Ariel Suhamy (Paris : Éditions Kimé, 2003).

26 Descartes, Passions of the Soul, art. 153 [AT XI 445-446/CSM II 384].

27 Descartes, Passions of the Soul, art. 152 [AT XI 445/CSM II 384].

28 E1p28.

29 For an interesting and subtle analysis that differs from mine, see Jean-Marie Beyssade, "Vix (Éthique IV Appendice chapitre 7) ou peut-on se sauver tout seul?," Revue de Métaphysique et de Morale 99, no. 4 (1994): 493-503.

30 E3p27. Freedom is a matter of the degree of activity we enjoy, but our activity must not be understood only as our ability to affect others while shielding ourselves from affection. It is also as our ability to concur with others. Sometimes we concur or come together with others by chance. Thus, Spinoza remarks in a letter that "of the things outside my power, I esteem none more than being allowed the honour of entering a pact of friendship with people who sincerely love the truth" [Ep. 19]. Friendship here is described as a matter of fortune, as something deeply beneficial that exceeds Spinoza's control. But the definition of generosity, as the rational desire to join others to oneself in friendship, suggests that sociability animated by a shared love of wisdom can be owed to the generosity of our wise friends. Perhaps what he esteems here is the power to form community or agreement [convenientia] that he has on occasion been fortunate to encounter in others.

31 E4app11. 
32 Emphasis added by Étienne Balibar in Spinoza: From Individuality to Transindividuality (Delft: Elburon, 1997), 21.

33 The idea of freedom as renunciation is not especially paradoxical on a dualist model, such as Descartes's, according to which virtue follows from disciplining the body according to the requirements of reason. See Pierre Macherey, Introduction à l'Éthique de Spinoza, tome 5: Les voies de la libération (Paris: Presses Universitaires de France, 1997), 36-37: "If freedom were purely a question of will, it would, with the same gesture, be enclosed within the paradox of a liberty that would be a manipulation, therefore an enslavement, or a subordination to an external order; instead of being the natural actualization of a power that liberates in liberating all that lies within it to do, insofar as it is a cause determined to produce effects that would naturally be its proper effects" (our translation).

34 See Descartes, Discourse on Method, Part Three [CSM II 122-126/AT VI 23-31].

35 E3da43.

36 E3da44.

37 E3p59s. In a provocative article Julie Cooper cites this as evidence that Spinoza advocates power through anonymity. See Julie Cooper, "Freedom of Speech and Philosophical Citizenship in Spinoza's Theological-Political Treatise," Law, Culture, and the Humanities 2, no. 1 (2006): 91-114.

38 Spinoza cites knowledge of God or Nature as that good that is increased rather than diminished by the enjoyment of all [E4p36]. He also points to theater, pleasant smells, and diverse foods as part of the life of the wise [E4p45s].

39 E4app14.

40 E5p10s.

41 For example, E2p49s and E4p37s1.

42 TP, ch. i, $\$ 1$.

43 E4p46s.

44 For example, "Minds, however, are conquered not by arms, but by love and generosity" [E4app11].

45 Macherey also contrasts this to the command to "turn the other cheek," in Pierre Macherey, Introduction à l'Éthique de Spinoza, tome 4: La condition humaine (Paris: Presses Universitaires de France, 1998), 273. Matthew Kisner, however, interprets E4p46 in line with Christian morality, in Matthew Kisner, Spinoza on Human Freedom: Reason, Autonomy, and the Good Life (Cambridge: Cambridge University Press, 2011), 205. If we think of the confrontational Christianity of Martin Luther King, Jr., who combines loving and martial language, Spinoza's words here are perhaps not so distant. See King's speech, "The sword that heals."

46 E4app7.

47 E4p35s. 